\title{
Dissolved nutrients of a high-latitude coral reef, Houtman Abrolhos Islands, Western Australia
}

\author{
C. J. Crossland ${ }^{1}$, B. G. Hatcher ${ }^{1}$, M. J. Atkinson ${ }^{2}$ and S. V. Smith ${ }^{2 *}$ \\ ${ }^{1}$ CSIRO Division of Fisheries Research, P. O. Box 20, North Beach, Western Australia 6020 \\ ${ }^{2}$ Zoology Department, University of Western Australia, Nedlands, Western Australia 6009
}

\begin{abstract}
Dissolved nutrients were monitored at 20 stations over a 2 yr period in the Easter Group of the Houtman Abrolhos Islands, Western Australia. Nutrient concentrations were greater inside the reef complex than concentrations in the oceanic region outside the island groups. Winter concentrations of dissolved organic phosphorus and nitrogen were high in the channels and along the islands, and reactive (inorganic) phosphate was high over the reef flats in winter. We suggest a mechanism for nutrient enrichment of the island groups whereby macroalgal material, torn by waves from the extensive algal stands along reef margins, is deposited inside the reef complex and through remineralization processes form a significant nutrient source in the lagoon.
\end{abstract}

\section{INTRODUCTION}

In the lagoonal coral reefs of the high-latitude Houtman Abrolhos Islands we have observed 4 phenomena we consider to be interrelated: (1) Macroalgal abundance is high in comparison with that of many more tropical coral reefs (Wilson and Marsh, 1979), and includes large stands of fucoid algae and kelp not typically found on coral reefs (Womersley, 1981). (2) Gross benthic community production of organic carbon is high, apparently reflecting the high algal biomass (Smith, 1981). (3) The lagoons of these reefs include large aggregations of unattached macroalgae and macroalgal fragments which undoubtedly contribute to a rich detritus-based food web, including a commercially important rock lobster fishery $\left(1.5 \times 10^{6} \mathrm{~kg}\right.$ live weight $\mathrm{yr}^{-1}$, 1961-71; Morgan and Barker, 1982). (4) The dissolved nutrient concentrations in the lagoons are apparently high (Johannes et al., 1983b) both in comparison with those of surrounding waters and in comparison with those of many other coral reefs (Kimmerer and Walsh, 1981; Crossland, in press). Here, we confirm the high seasonally-sustained, nutrient levels in the Houtman Abrolhos lagoons. Further, we attempt to tie these phenomena together into a unified model of nutrient cycling in this reef system.

\footnotetext{
- Present address: Hawail Institute of Marine Biology, P.O. Box 1346, Kaneohe, Hawaii 96344, USA
}

\section{Study area}

The Houtman Abrolhos Islands are located between $28^{\circ}$ and $29^{\circ} \mathrm{S}$ near the edge of the continental shelf of Western Australia. The biological community structure of these islands and their associated reefs has been outlined by Wilson and Marsh (1979). Most habitats of tropical coral reefs are found in the Houtman Abrolhos Islands. Compared with other reefs of similar latitude, the hermatypic coral diversity of the Houtman Abrolhos Islands is high, viz., 37 genera represented by about 70 species, Acropora spp. and Montipora spp. being most abundant. However, other faunal groups are relatively impoverished and composed of mixed southern temperate, west-coast endemic, and northern tropical species.

Fleshy macroalgae form a major component of the benthic communities of the reefs; a feature common to other high latitude coral reefs (e.g. Lord Howe Island, (Veron and Done, 1979), Bahamas, (Lighty, 1982). The high-energy outer reef slopes support rich and dense macrophyte communities characterized by large brown algae (e.g. Dictyota, Glossophora, Sargassum) including the kelp Ecklonia radiata, mixed with fleshy red and green algae (e.g. Asparagopsis, Hypnea, Laurencia, Plocamium, Caulerpa). Seasonally-changing macroalgal communities dominate many protected reef areas within the lagoons. Large Phaeophytes, including species of Caulocystis, Cystophyllum, Hor- 
mophysa, Sargassum and Turbinaria, are common in summer, with other fleshy algae (e.g. Eucheuma, Laurencia) covering shallow reef areas in spring (Rimmer, pers. comm.).

Smith (1981) measured unusually high gross primary production during both winter and summer in reef flat and lagoonal patch reef communities of the Easter Group and attributed this to a high biomass of autotrophs (both corals and fleshy algae). An annual gross production to respiration ratio average of $0.97(0.84$, winter; 1.07 , summer) was calculated for the lagoonal patch reef.

The Houtman Abrolhos Islands are influenced by a strong southerly current, the Leeuwin Current, which flows along the edge of the continental shelf of Western Australia, especially during winter (Cresswell and Golding, 1980). The limited nutrient data available for the offshore waters indicate low concentrations for inorganic $\mathrm{N}$ and $\mathrm{P}$ (Rochford, 1980).

\section{METHODS}

Surface water samples were collected from 20 stations near Rat Island at 4 to 6 week intervals between November 1979 and December 1981 (Fig. 1 shows location of stations).

Each $120 \mathrm{ml}$ water sample was filtered through a $0.45 \mu \mathrm{m}$ Sartorius membrane and stored in a plastic Whirlpac bag with $1.0 \mathrm{ml}$ mercuric chloride solution $\left(2.5 \mathrm{~g}^{-1}\right)$. Samples were transported to Perth for analysis. Each water sample was analysed for reactive phosphate (inorganic, RP), dissolved organic phosphorus (DOP), nitrate $\left(\mathrm{NO}_{3}\right)$, nitrite $\left(\mathrm{NO}_{2}\right)$, dissolved organic nitrogen (DON), and silicate (Si). Standard methods for nutrient analyses (Strickland and Parsons, 1972) were modified for small sample volumes (5-10 ml). DOP and DON were determined by persulfate oxidation (DOP, Menzel and Corwin, 1965; DON, D'Elia et al., 1977).

Additional samples were collected in winter (June 1979) from the lagoon and reef flat areas west of Rat Island and from the Wallaby and Pelsart Groups (Fig. 1). These $1 \mathrm{l}$ samples were analysed for particulate organic carbon (POC), nitrate-nitrite ( $\mathrm{NO}_{3}^{-}+\mathrm{NO}_{2}^{-}$), ammonium $\left(\mathrm{NH}_{4}^{+}\right)$, and reactive phosphorus (RP) (Strickland and Parsons, 1972).

\section{RESULTS}

Mean concentrations of dissolved inorganic and organic nutrients showed no significant seasonal pattern in the 2 yr of sampling (Fig. 2, 3 and 4). In general, there were no clear seasonal trends at specific sites -

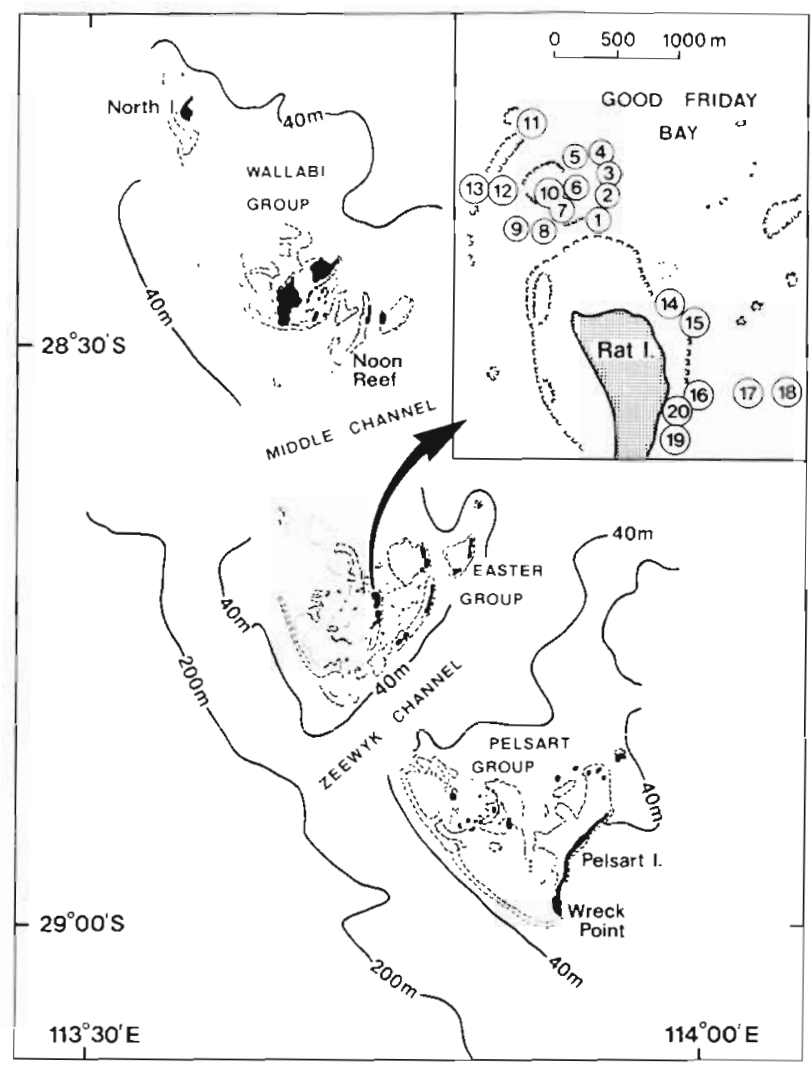

Fig. 1. Houtman Abrolhos Island Groups. Inset showing study sites and nutrient sampling stations near Rat Island

except that DOP and DON were higher during winter in the reef channels and along the eastern front of Rat Island, and RP was higher during this period over the reef flats.

Temporal variations in nutrient concentrations did occur over time scales other than seasonal, for example, long-term (year-to-year) and short-term (minutesto-hours) (Johannes et al., 1983a). The short-term variability probably reflects spatial inhomogeneities resulting from complex mixing of waters within the reef system.

The 1981 summer and winter mean concentrations of RP, DOP, and DON were significantly higher than the 1980 mean values $(p<0.05$, from 1 -way ANOVA and Welsch Step-up procedure; Sokal and Rohlf, 1979). These higher concentrations in 1981 (year-to-year variations) were not significantly correlated with obvious physical factors such as storm frequency, storm intensity or rainfall. Table 1 is a summary of dissolved inorganic nutrient and POC concentrations during June 1979 for the 3 island groups.

The overall results of the monitoring program reveal that the nutrient concentrations in the island groups are consistently higher than those in the nearby ocean viz, 0.05 to $0.25 \mu \mathrm{M} \mathrm{NO}$ in offshelf and continental 


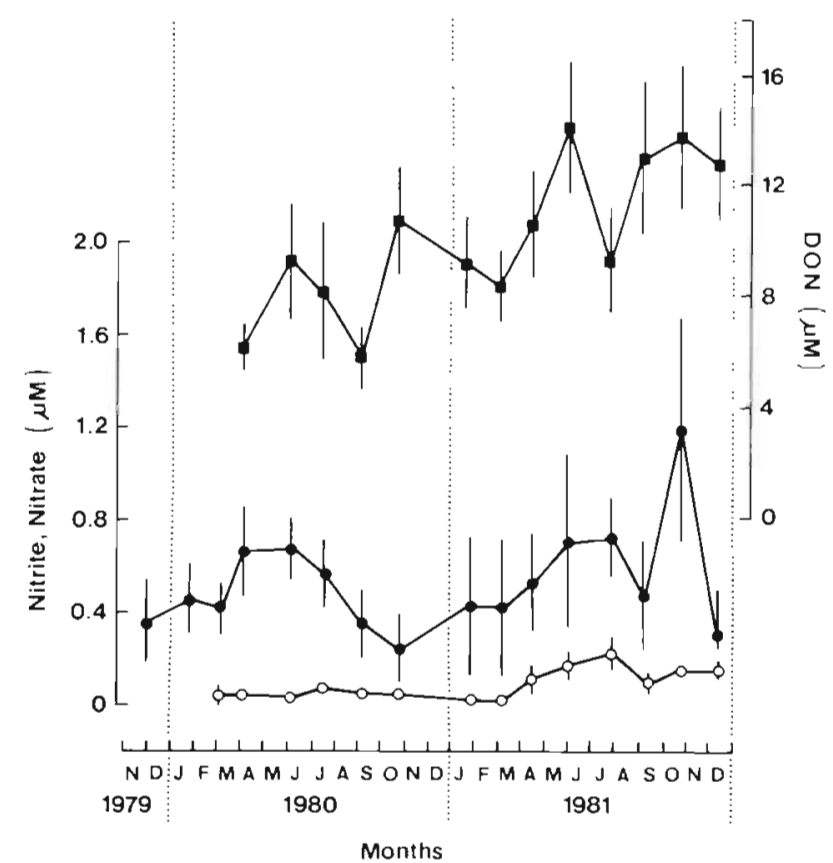

Fig. 2. Dissolved nitrogen concentrations in surface waters at Rat Island. Nitrate, nitrite and dissolved organic nitrogen (DON) shown as mean values \pm standard deviation $(n=20)$

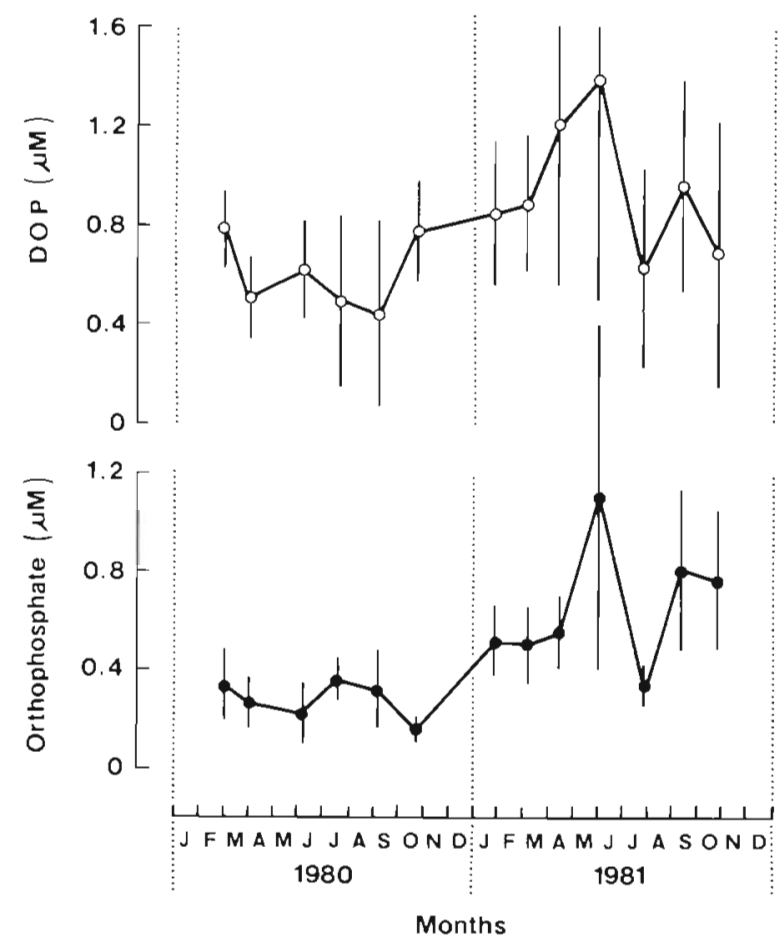

Fig. 3. Dissolved phosphorus concentrations in surface waters at Rat Island. Reactive phosphorus and dissolved organic phosphate (DOP) shown as mean values \pm standard deviation $(\mathrm{n}=20)$

shelf waters (France, pers. comm.; CSIRO Hydrographic Station, Geraldton, unpubl.) and $<0.2 \mu \mathrm{M} R \mathrm{RP}$ in offshelf waters (Rochford, 1962, 1967, 1980).

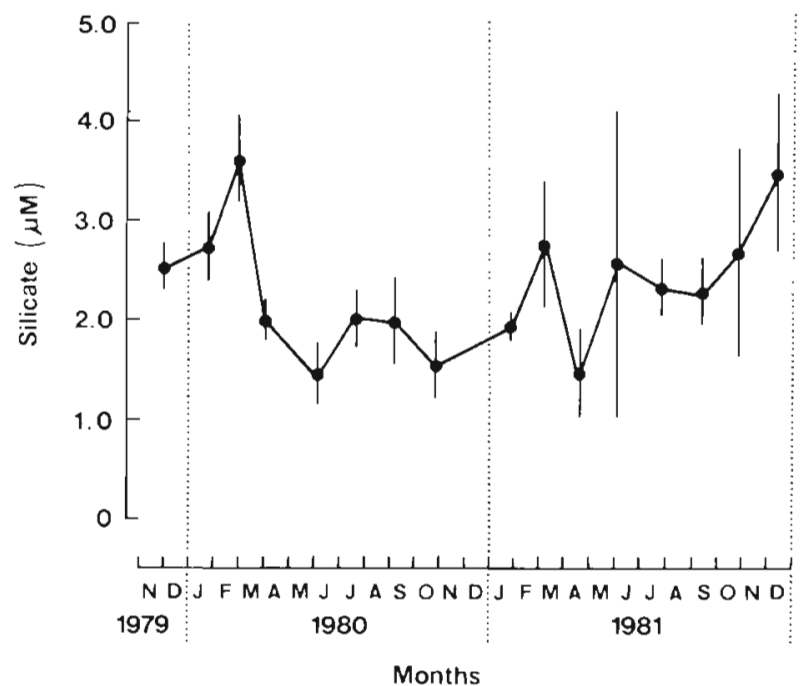

Fig. 4. Silicate concentrations in surface waters at Rat Island Mean values \pm standard deviations $(n=20)$

Table 1. Dissolved inorganic nitrogen, reactive phosophorus (RP), and particulate organic carbon (POC) concentrations in Houtman Abrolhos Island waters, June 1979. Mean values of triplicate samples from each site

\begin{tabular}{|c|c|c|c|c|}
\hline Sample site & $\begin{array}{l}\mathrm{NH}_{4}^{+} \\
(\mu \mathrm{M})\end{array}$ & $\begin{array}{c}\mathrm{NO}_{3}^{-}+\mathrm{NO}_{-}^{-} \\
(\mu \mathrm{M})\end{array}$ & $\begin{array}{c}\mathrm{RP} \\
(\mu \mathrm{M})\end{array}$ & $\begin{array}{c}\mathrm{POC} \\
\left(\mathrm{mg} \mathrm{l}^{-1}\right)\end{array}$ \\
\hline \multicolumn{5}{|c|}{ Pelsaert Group (W. of Wreck Pt.) } \\
\hline Front reef flat & 0.17 & 0.83 & 0.26 & 1.52 \\
\hline Back reef flat & 0.22 & 0.86 & 0.26 & 0.53 \\
\hline Lagoon slope & 0.28 & 0.91 & 0.31 & 0.87 \\
\hline \multicolumn{5}{|c|}{ Easter Group (Western reef) } \\
\hline Front reef flat & 0.21 & 1.02 & 0.22 & 0.87 \\
\hline Back reef flat & 0.28 & 0.96 & 0.24 & 0.76 \\
\hline $\begin{array}{l}\text { Lagoon } \\
\text { (W. of Rat Is.) }\end{array}$ & 0.32 & 0.93 & 0.29 & 0.33 \\
\hline \multicolumn{5}{|c|}{ Wallabi Group ((W. of Noon Reef) } \\
\hline $\begin{array}{l}\text { Reef flat } \\
\text { (Three Sisters) }\end{array}$ & 1.95 & 1.50 & 0.50 & 0.94 \\
\hline $\begin{array}{l}\text { Reef flat } \\
\text { (N, Noon Reef) }\end{array}$ & 0.23 & 1.04 & 0.41 & 1.50 \\
\hline Lagoon & 0.30 & 1.19 & 0.43 & 0.62 \\
\hline
\end{tabular}

\section{DISCUSSION}

The high concentrations of nutrients inside the lagoons of these island groups, relative to the outside oceanic concentrations, indicate that there must be sources of nutrient delivery to the lagoons other than ocean water.

Enrichment of surface waters by deep-layer nutrients along the island shelf, land runoff, and net nutrient flux from the benthos to the water column have 
been identified as factors leading to localized high mutrient concentrations in inshore waters of other islands (see Sanders, 1981). However, there is no evidence of localized upwelling along the Western Australian shelf margin (Rochford, 1980), so we can dismiss the possibility that ocean water entering the lagoons of the Houtman Abrolhos Islands differs significantly from that of offshelf surface water conditions. Nutrient enrichment resulting from seasonal runoff is unimportant adjudged from the lack of any seasonal changes in the surface water nutrient concentrations near Rat Island and the limited emergent land mass of the islands. Groundwater delivery occurs along much of the Western Australian coastline (Johannes, 1980), but from his observations (pers, comm.) it does not appear to account for a significant nutrient delivery to the Houtman Abrolhos Islands.

As nutrient concentrations are higher inside the lagoons than outside, horizontal mixing must deliver nutrients from the lagoons back to the ocean. To gain an order of magnitude estimate of nutrient flux we have assumed a circular configuration of $20 \mathrm{~km}$ diameter with $5 \mathrm{~m}$ average lagoon depth for the Easter Group and evaluated RP. Phosphorus is a useful parameter for budgeting long-term net production in marine communities (Atkinson, 1982); nitrogen is not, mainly due to variable nitrogen fixation activity (Smith and Atkinson, in press). Calculations suggest that at least $10^{3}$ moles $\mathrm{P} \mathrm{d}^{-1}$ are lost from the Easter Group. If this loss were to occur without renewal, we estimate that the $P$ trapped in sediments and biota of the reefs (of the order of $10^{6}$ moles P) would be depleted in about $3 \mathrm{yr}$. We must turn to alternative explanations for nutrient supply to, and maintenance within the Houtman Abrolhos Island groups.

We suggest another mechanism to account for the biotic-nutrient observations. Net macroalgal growth on the forereef slopes of these island groups is supported by large oceanic advection of nutrients (at low concentrations, but large water flow). Many of these algae are continuously eroded by wave action (e.g. Mann and Kirkman, 1981) and are torn loose during storms, particularly during late autumn and winter. The pattern of water movement across these reefs ensures that much of this algal material is transported into the lagoons. Large fragments of macroalgae are common in the water traversing the reef crest to the lagoons and algal particulates are commonly observed in the lower water column of the windward reef flats of the Pelsaert and Easter Groups (c.f. POC values, Table 1). A series of 6 particulate traps $\left(0.25 \mathrm{~m}^{2}, 1 \mathrm{~mm}\right.$ mesh; c.f. Johannes and Gerber, 1974), deployed on the western reef crest of the Easter Group during October 1982, yielded 180 to 460 (mean 300 ) $\mathrm{g}$ dry weight $\mathrm{m}^{-1}$ crest $\mathrm{d}^{-1}$ input to the lagoon. This represents an excess of $10^{2}$ moles $P$ $\mathrm{d}^{-1}$ imported to the lagoon over the reef crest in this particulate fraction alone. Floating rafts of algae are common in protected areas. While some of these rafts are lost to the surrounding continental shelf waters (especially those comprised of Caulocystis, CystophylIum and Sargassum; algae produced on the reef flats and lagoonal patch reefs), many of the rafts eventually sink to the bottom of the lagoons where extensive accumulations of algae may be found (up to $1 \mathrm{~m}$ deep). We assume this material decomposes and releases nutrients back to the water column. Thus, the production of algal material on the reef slopes, transportation to the lagoons where it is trapped and remineralized, and the oceanographic transfer of nutrients back to the sea characterize the nutrient cycle of this system. The lagoons may be viewed as heterotrophic components of the system responding to autotrophic activity on the reef slopes.

The high lagoonal nutrient concentrations may well stimulate the specific growth rates of algae in the lagoon (Steffersen, 1976; De Boer et al., 1978; Topinka, 1978; Prince and O'Neal, 1979). However, our model suggests that these high nutrient levels are indicative of net community heterotrophy for the lagoonal subsystem of the total forereef-lagoon system. Two features distinguish the system from other, superficially similar systems which have been more extensively studied, i.e. coral reefs and coastal kelp beds. First, most coral reefs apparently lack a large macroalgal biomass (Cribb, 1981). In fact, the large fucoid algae and kelp, which are abundant on the forereef slopes of the Houtman Abrolhos Islands, are typically temperate water algae (Womersley, 1981). Furthermore, the bulk of algal production on coral reef slopes enters grazing rather than detrital food webs (Bakus, 1967, 1972; Hatcher, 1982). Therefore, high rates of algal detritus generation with subsequent dispersal, remineralization, and nutrient elevation are unlikely to be conspicuous features of most coral reefs (Marsh, 1976). Second, areas with a large biomass of fucoids and kelps often lack distinctive basins like reef lagoons in which to localize and accumulate detritus. Thus, the spatial separation of autotrophy and heterotrophy (exemplified by low and high nutrient concentrations in this instance) is not as conspicuous for many macroalgal-dominated ecosystems as it is in the Houtman Abrolhos Islands.

We conclude that this large-scale separation of autotrophic and heterotrophic communities, though more conspicuous in the Houtman Abrolhos Islands than in many other systems, is an important characteristic of ecosystem metabolism. It may also account in part for the sustained high yield of the lobster fishery at the Houtman Abrolhos Islands. Such fisheries are rare on most tropical coral reefs (Morgan, 1980). 
Acknowledgements. We thank our colleagues in the CSIRO Coastal Ecosystem Group, Western Regional Laboratories, Marmion for helpful discussion and assistance, particularly R. E. Johannes, D. Rimmer, and W. J. Wiebe. R. France, Geology Department, University of Western Australia provided nutrient data on shelf-oceanic waters around the Houtman Abrolhos Islands.

\section{LITERATURE CITED}

Atkinson, M. J. (1982). Phosphate flux as a measure of net coral reef flat production. Proc. Fourth Int Symp. Coral Reefs, Manila, 1981, 1:417-418

Bakus, G. J. (1967). The feeding habits of fishes and primary production at Eniwetok, Marshall Islands. Micronesica 3: $135-149$

Bakus, G. J. (1972). Effects of the feeding habits of coral reef fishes on the benthic biota. Proc. Symp. Coral and Coral Reefs, Cochin, p. 445-448

Cresswell, G. R., Golding, T. J. (1980). Observations of a south-flowing current in the southeastern Indian Ocean. Deep Sea Res. 27 A: 449-466

Cribb, A. B. (1981). Coral reefs. In: Clayton, M. N., King, R. J. (ed.) Marine botany: an Australasian perspective. Longman Cheshire, Melbourne, p. 330-345

Crossland, C. J. (in press). Dissolved nutrients in coral reefs. In: D. J. Barnes (ed.) Perspectives on coral reefs. Australian Institute of Marine Science, Townsville

De Boer, J. A., Guigli, H. J., Israel, T. L., D'Elia, C. F. (1978). Nutritional studies of two red algae. I. Growth rate as a function of nitrogen source and concentration. J. Phycol. 14: 261-266

D'Elia, C. F., Steudler, P. A., Corwin, N. (1977). Determination of total nitrogen in aqueous samples using persulfate digestion. Limnol. Oceanogr. 22: 760-764

Hatcher, B. G. (1982). The interaction between grazing organisms and the epilithic algal community of a coral reef: a quantitative assessment. Proc. Fourth Int. Symp. Coral Reefs, Manila, 1981, 2: 515-524

Johannes, R. E. (1980). The ecological significance of the submarine discharge of groundwater. Mar. Ecol. Prog. Ser. 3: $365-373$

Johannes, R. E., Gerber, R. (1974). Import and export of net plankton by an Enewetak coral reef community. Proc Second Int. Symp. Coral Reefs 1: 97-104

Johannes, R. E., Wiebe, W. J., Crossland, C. J. (1983a). Three patterns of nutrient flux in a coral reef community. Mar. Ecol. Prog. Ser. 12: 131-136

Johannes, R. E., Wiebe, W. J., Crossland, C. J., Rimmer, D. W. Smith, S. V (1983b). What sets latitudinal limits on coral reef growth? Mar. Ecol. Prog. Ser. 11. 105-111

Kimmerer, W. J., Walsh, T W. (1981). Tarawa Atoll Lagoon: circulation, nutrient fluxes and the impact of human waste. Micronesica 17: 161-179

Lighty, R. G. (1982). Fleshy-algal domination of a modern Bahamian Barrier reef: example of an alternative climax reef community. Proc. Fourth Int. Symp. Coral Reefs, Manila, 1981: 722

Mann, K. H., Kirkman, H. (1981). A biomass method for measuring productivity of Ecklonia radiata with the potential for adaptation to other large brown algae. Aust J. mar. Freshw. Res 32: 151-164

Marsh, J. A. (1976). Energetic role of algae in reef ecosystems Micronesica 12: 13-21

Menzel, D. W., Corwin, N. (1965). The measurement of total phophorus in seawater based on the liberation of organically bound fractions by persulphate oxidation. Limnol. Oceanogr 10: 280-282

Morgan, G. R. (1980). Population dynamics of spiny lobsters. In: Cobb. J. S., Phillips, B. F. (ed.) The biology and management of lobsters, Vol. II. Ecology and management. Academic Press, New York, p. 189-217

Morgan, G. R., Barker, E. H. (1982). The western rock lobster fishery, 1961-71. Dept. Fish. Wildlife W. Aust. Rept. No. 55: 1-4 1

Prince, J. S., O'Neal, S. W. (1979). The ecology of Sargassum pteropleuron (Phaeophyceae, Fucales) in waters off South Florida. I. Growth, reproduction and population structure. Phycologia 18: 109-114

Rochford, D. J. (1962). Hydrology of the Indian Ocean. II. The surface waters of the South-East Indian Ocean and Arafura Sea in the spring and summer. Aust. J. mar. Freshwat. Res. 13: 226-251

Rochford, D. J. (1967). The phosphate levels of the major surface currents of the Indian Ocean. Aust. J. mar. Freshwat. Res. 18: $1-22$

Rochford, D. J. (1980). Nutrient status of the oceans around Australia. CSIRO Aust. Div. Fish. Oceanogr Ann. Rep. 1977-1979: 9-20

Sanders, F. (1981). A preliminary assessment of the main causative mechanisms of the 'Island Mass' effect of Barbados. Mar. Biol. 64: 199-205

Smith, S. V. (1981). The Houtman Abrolhos Islands: carbon metabolism of coral reefs at high latitude. Limnol Oceanogr. 26: 612-621

Smith, S. V., Atkinson, M. J. (in press). Organic production, sediment composition and nutrient limitation in a hypersaline bay. Nature, Lond.

Sokal, R. R., Rohlf, F. J. (1979). Biometry: the principles and practice of statistics in biological research, 2nd ed. W. H. Freeman and Co., San Francisco

Steffersen, D. A. (1976). The effect of nutrient enrichment and temperature on the growth in culture of Ulva lactuca $\mathrm{L}$. Aquat. Bot. 2: 337-351

Strickland, J. D. H., Parsons, T. R. (1972). A practical handbook of seawater analysis, 2 nd ed. Bull. Fish. Res. Bd Can 167: $1-310$

Topinka, J. A. (1978). Nitrogen uptake by Fucus spiralis (Phaeophyceae). J. Phycol. 14: 241-247

Veron, J. E. N., Done, T. J. (1979). Corals and coral communities of Lord Howe Island. Aust. J. mar. Freshwat. Res. 30: $203-36$

Wilson, B. R., Marsh, L. M. (1979). Coral reef communities at the Houtman Abrolhos, Western Australia, in a zone of biogeographic overlap. Proc. Int. Symp. Mar. Biogeography and Evolution in the Southern Hemisphere, 1978. N. Z. DSIR Information Series 137: 259-278

Womersley, H. B. S. (1981). Biogeography of Australasian marine macroalgae. In: Clayton, M. N., King, R. J. (ed.) Marine botany: an Australasian perspective. Longman Cheshire, Melbourne, p. 293-307 